\title{
Microbiological assessment of indoor air in public toilets across selected motor parks in Owerri Metropolis, Nigeria
}

\begin{abstract}
In this study, the microbial quality of indoor air in public toilets across selected motor parks in Owerri was carried out and the type of airborne microbes in the various toilets identified. Public toilets located in four motor parks in the city were examined for air borne microbial load. The sedimentation technique using open petri-dishes containing Blood Agar and Sabouraud Dextrose Agar (SDA) placed one meter above the floor of the toilets for 15 minutes at different sections of the toilets was used. This was transported to a microbiology laboratory in a clean container for analysis. Bacterial isolates were identified using standard microbiological techniques which include cultural, morphological, microscopic examination and different biochemical tests. While fungal isolates were identified using standard procedures based on colony appearance, microscopic examination of spores and hyphal characteristics of lactophenol cotton blue preparation. Six bacterial and fungal isolates were obtained respectively which include Staphylococcus aureus (38), Bacillus sp (24), Bacillus cereus (19), Staphylococcus epidermidis (10), Streptococcus sp (4), Enterococcus sp (2) and Fusarium sp (15), Mucor sp (13), Aspergillus sp (10), Candida sp (8), Rhizopus sp (8) and Penicillium sp (3), in which the Imo transport company Motor park (ITC) toilets had the highest bacterial and fungal occurrence of $30.9 \%$ and $31.6 \%$ respectively. Bacterial colony count ranged from $83.3 \mathrm{cfu} / \mathrm{m}^{3}$ in ITC Motor Park to $63.5 \mathrm{cfu} / \mathrm{m}^{3}$ in Mbaise Motor Park. While the fungal colony count ranged from $33.4 \mathrm{cfu} / \mathrm{m}^{3}$ in ITC Motor Park to $20.5 \mathrm{cfu} /$ $\mathrm{m}^{3}$ in Arugo Motor Park. The inevitable inhalation and contact with some of these microbes by visitors and drivers in these motor parks could pose a serious health threat especially among highly sensitive individuals. Therefore, necessary steps should be taken by the management of these motor parks to forestall undesirable consequences.
\end{abstract}

Volume 5 Issue 6 - 2017

\author{
Promise Ifunanya Ohagim,' Grace Michael \\ Ikon, ${ }^{2}$ Precious Chika Matthew, ${ }^{3}$ Gold \\ Amarachi Ohagim ${ }^{4}$ \\ 'Department of Medical Microbiology and Parasitology, \\ University of Uyo, Nigeria \\ ${ }^{2}$ Department of Microbiology, Obong Universty, Nigeria \\ ${ }^{3}$ Department of Microbiology, Federal University of Technology, \\ Nigeria \\ ${ }^{4}$ Department of Biology, University of Nigeria, Nigeria
}

Correspondence: Promise Ifunanya Ohagim, Department of Medical Microbiology and Parasitology, University of Uyo, Uyo, Nigeria,Email pohagim26@gmail.com

Received: September 12, 2017| Published: September 28, 2017

Keywords: indoor air, public toilets, motor park, microbial load

Abbreviations: SDA, sabouraud dextrose agar; ITC, imo transport company; CFU, colony forming units

\section{Introduction}

Indoor air quality is defined as the quality of air within and around buildings and structures, and its significance especially in relation to health and comforts of occupants. ${ }^{1}$ The quality of air inhaled by an individual within an environment in which the individual finds himself determines to a great extent, the well-being of that individuals. ${ }^{2}$. In recent years, indoor air quality has become a topic of serious concern, since most people spend their indoors, either in their house, office, school or other public places, where they are exposed to some indoor microorganisms which have much effects on their health and physical condition. ${ }^{2}$

Toilets are one of the public facilities frequently used by people and are located indoor. Therefore, maintaining good air quality in toilets is essential in order to keep it hygienic and sanitarily conducive for usage. ${ }^{1}$ In order to create a healthier and safer indoor environment, the first step is to maintain a good indoor air in toilets and washrooms. ${ }^{3}$ Air is the easiest means by which agents of pathogenic microbes are disseminated, which can cause significant problems in the environment; especially, in public rooms such as toilets. ${ }^{3}$ Insufficient ventilation, high influx of people and improper management of public toilets, are main sources of indoor air contamination in public toilets.

Transmission of pathogenic organisms can be direct or indirect. In direct transmission, droplets containing microbial agents from individuals can be released into the air, which when inhaled by another can lead to an infection. Droplets are generated mainly through coughing, sneezing, and other procedures. Dissemination can be either by airborne droplets containing the organisms that remain suspended in the air for a long period of time or dust particles containing the infectious agents. ${ }^{5}$ Indirect transmission can occur through contact with contaminated surfaces and objects or through insect vectors.

A motor park is a vehicle station for passengers to get on or off buses or taxis. It also serves as a waiting spot and in some cases a recreational and relaxation spot for travelers, as people wait for their families and friends returning or wait for their buses or taxis to depart. The moor park is a beehive of activities and with the influx of people into the parks, the toilets become a point of call and place of relief for pressed drivers, travelers and others who may wish to ease themselves. This usually leaves the toilets untidy and littered, making it a haven of airborne pathogens.

Studies have been conducted regarding indoor air in toilets located in four-bed hospital wards and conventional portable toilets. The results revealed that the wetness of toilets, lack of litter bins and refuse lids and lack of ownership of some public toilets are the most contributing factors to the problem of hygiene and dirtiness of public toilets. These automatically impacts on the indoor air quality of these toilets. ${ }^{6}$

Microorganisms are ubiquitous and propagate rapidly wherever water is available. The dust and dirt's normally present in most public toilets provide sufficient nutrients to support extensive microbial 
growth. ${ }^{5}$ Mould specifically grows on all materials, including the dirty toilet bins and under the toilet seats; following the damp nature of most toilets, leading to mould growth. Microbial growth may result in greater numbers of spores, cell fragments, allergens, mycotoxins, endotoxins, $\beta$-glucans and volatile organic compounds in indoor air. The causative agents of adverse health effects have not been identified conclusively, but an excess level of any of these agents in the indoor environment is a potential health hazard. ${ }^{1}$. Microbial interactions and moisture-related physical and chemical emissions from toilet materials may also play a role in dampness-related health effects. ${ }^{4}$

However, the drivers of these motor parks that are not the only set of people at risk of airborne infections, as visitors and travelers are also at risk of being infected. Hence, this study was carried out to investigate microbial quality of indoor air in public toilets across selected motor parks in Owerri and to identify the type of airborne microbes in the various toilets.

\section{Materials and methods}

\section{Study area}

This study was carried out in motor parks located in Owerri, Imo state of Nigeria. Owerri is the capital of Imo state, Southeastern Nigeria. It covers an area of $40.15 \mathrm{sq}$ mi, with a weather which is $750 \mathrm{~F}(240 \mathrm{C})$ and a $95 \%$ humidity. It has a population of over 401,873 (Census, 2006), and a tropical wet climate with rain falls for most months of the year accompanied with a brief dry season.

\section{Sample collection}

Samples were collected from the following motor parks across Owerri; Imo transport company Motor park (ITC), Arugo Motor Park, Mbaise Motor Park and Okigwe Motor Park. The choice of these parks was as a result of the beehive of activities that goes on there daily, being among the major motor parks in the city. Samples were collected twice daily from these locations; 30 minutes after the toilets must have been cleaned and dust allowed to settle. Mornings (7:30am-9am) and evenings (4.30pm-6pm) between June and July, 2017 for an interval of 7 days. Sedimentation technique using open petri-dishes containing Blood Agar and Sabouraud Dextrose Agar (SDA) was used. ${ }^{7}$ Each plate was placed one meter above the floor of the toilets for 15 minutes at different sections of the toilets (male and female). This was later transported in a clean container to the laboratory for incubation and microbiological examination.

\section{Microbiological analysis}

Blood agar plates were incubated at $37^{\circ} \mathrm{C}$ for $24-48$ hours, while the SDA plates were incubated at room temperature at $25^{\circ} \mathrm{C}-30^{\circ} \mathrm{C}$ for 3-5 days. Microbial growths were isolated and enumerated for airborne bacteria on blood agar plates and airborne fungi on SDA plates. The total number of colony forming units (CFU) for fungi and bacteria were determined after incubation and converted to organism colony forming units per cubic meter $\left(\mathrm{CFU} / \mathrm{M}^{3}\right)$ using the formula $\mathrm{CFU} / \mathrm{M}^{3}=\mathrm{CFU} / \mathrm{txk}$. where $\mathrm{CFU}=$ mean of colony forming unit, $\mathrm{t}=$ total sampling time expressed in minutes, $\mathrm{k}=\mathrm{a}$ conversion factor from cubic feet to cubic meters $(\mathrm{k}=35.3)$.

\section{Bacterial identification}

Bacterial isolates were characterized and identified using cultural, morphological and microscopic examinations. Different biochemical tests such as Gram staining, Catalase, Coagulase, DNase, Methyl-red, Oxidase, Voges-proskauer and sugar fermentation test were employed to differentiate the bacterial isolates. ${ }^{8}$

\section{Fungal identification}

Fungi colonies were identified using standard microbiological procedures based on their colony appearance, microscopic examination of their spores and hypal characteristics using lactophenol cotton blue preparation. ${ }^{9}$

\section{Statistical analysis}

Simple percentage was used to express the frequency of occurrence of bacterial isolates where necessary.

\section{Results}

The frequency of bacterial species isolated and characterized from the different toilets of the motor parks is represented on Table 1. The distribution of the isolates are as follows; Staphylococcus aureus (38), Bacillus sp (24), Bacillus cereus (19), Staphylococcus epidermidis (10), Streptococcus sp (4) and Enterococcus sp (2). Imo transport company Motor park (ITC) toilets had the highest bacterial occurrence of $30.9 \%$, followed by Arugo Motor Park toilets $25.8 \%$, while those of Mbaise Motor Park had the least bacterial occurrence of $20.6 \%$.

Table 2 represents the frequency of fungi species isolated from the sampled motor parks. The occurrence of the fungal isolates is as follows; Fusarium sp (15), Mucor sp (13), Aspergillus $s p$ (10), Candida sp (8), Rhizopus sp (8) and Penicillium sp (3). The highest fungal occurrence was obtained in Imo transport company Motor Park (ITC) toilets with 31.6\%, followed by Okigwe Motor Park toilets $26.3 \%$, while those of Arugo Motor Park had the least fungal occurrence of $19.3 \%$.

The frequency of microbial loads of the various toilets in the motor parks sampled is represented on Table 3. The toilets of Imo Transport Company Motor Park had the highest bacterial colony count of $83.3 \mathrm{cfu} / \mathrm{m}^{3}$, followed by those of ArugoMotor Park $67.3 \mathrm{cfu} /$ $\mathrm{m}^{3}$ while those of Mbaise Motor Park had the lowest colony count of $63.5 \mathrm{cfu} / \mathrm{m}^{3}$. The Imo Transport Company Motor Park also had the highest fungal colony count of $33.4 \mathrm{cfu} / \mathrm{m}^{3}$, followed by MbaiseMotor Parkwith $28.9 \mathrm{cfu} / \mathrm{m}^{3}$, while Arugo Motor Park had the least colony count of $20.5 \mathrm{cfu} / \mathrm{m}^{3}$.

Table I Frequency of Bacteria species Isolated from the Sampled Motor Parks ( $n=97)$

\begin{tabular}{|c|c|c|c|c|c|}
\hline Organisms & No. of Isolates & ITC park & Arugo park & Okigwe park & Mbaise park \\
\hline Bacillus sp & 24 & $9(37.5)$ & $4(16.7)$ & $5(20.8)$ & $6(25.0)$ \\
\hline Bacillus cereus & 19 & $6(31.6)$ & $5(26.3)$ & $4(2 I .1)$ & $4(2 I . I)$ \\
\hline Enterococcus sp & 2 & $I(50.0)$ & - & - & $I(50.0)$ \\
\hline Streptococcus sp & 4 & $2(50.0)$ & $I(25.0)$ & $I(25.0)$ & - \\
\hline Staphylococcus aureus & 38 & $9(23.7)$ & $12(31.6)$ & $10(26.3)$ & $7(18.4)$ \\
\hline Staphylococcus epidermidis & 10 & $3(30.0)$ & $3(30.0)$ & $2(20.0)$ & $2(20.0)$ \\
\hline Total & 97 & $30(30.9)$ & $25(25.8)$ & $22(22.7)$ & $20(20.6)$ \\
\hline
\end{tabular}


Table 2 Frequency of Fungi species Isolated from the Sampled Motor Parks $(n=57)$

\begin{tabular}{llllll}
\hline Organisms & No. of isolates & ITC motor park & Arugo motor park & Okigwe motor park & Mbaise motor park \\
\hline Fusarium $s p$ & $\mathrm{I} 5$ & $4(26.7)$ & $3(20.0)$ & $5(33.3)$ & $3(20.0)$ \\
Rhizopus sp & 8 & $3(37.5)$ & $2(25.0)$ & $\mathrm{I}(\mathrm{I} 2.5)$ & $2(25.0)$ \\
Mucor sp & $\mathrm{I} 3$ & $4(30.8)$ & $3(23 . \mathrm{I})$ & $4(30.8)$ & $2(\mathrm{I} 5.4)$ \\
Aspergillus sp & $\mathrm{I} 0$ & $3(30.0)$ & $\mathrm{I}(\mathrm{I} 0.0)$ & $2(20.0)$ & $4(40.0)$ \\
Candida sp & 8 & $3(37.5)$ & $2(25.0)$ & $2(25 . .0)$ & $\mathrm{I}(\mathrm{I} 2.5)$ \\
Penicillium $s p$ & 3 & $\mathrm{I}(33.3)$ & - & $\mathrm{I}(33.3)$ & $\mathrm{I}(33.3)$ \\
Total & 57 & $\mathrm{I}(3(3 \mathrm{I} .6)$ & $\mathrm{II}(19.3)$ & $\mathrm{I}(26.3)$ & $\mathrm{I}(22.8)$ \\
\hline
\end{tabular}

Table 3 Bacterial and Fungal Colony Forming Unit $\left(C F U / M^{3}\right)$ according to Motor Parks $(n=10)$

\begin{tabular}{lllll}
\hline Motor Parks & Bacterial colony & & \multicolumn{2}{l}{ Fungal colony } \\
\cline { 2 - 5 } & CFU(Mean) & CFU/M & CFU(Mean) & CFU/M \\
\hline ITC Park & 38.4 & 83.3 & 14.2 & 33.4 \\
Arugo Park & 28.6 & 67.3 & 8.7 & 20.5 \\
Okigwe Park & 27.7 & 65.2 & 10.8 & 25.4 \\
Mbaise Park & 27 & 63.5 & 12.4 & 28.9 \\
\hline
\end{tabular}

Key $n=$ No. of sampling in the morning and evenings for 5 days.

\section{Discussion}

The investigation of the quality of indoor air in public toilets across selected motor parks in Owerri showed that the Imo Transport Company (ITC) Motor Park toilet had the highest air borne bacterial and fungal colony count of $83.3 \mathrm{cfu} / \mathrm{m}^{3}$ and $33.5 \mathrm{cfu} / \mathrm{m}^{3}$ respectively, when compared to the toilets of other motor parks. The toilets in other motor parks also recorded high bacterial colony count $67.3 \mathrm{cfu} / \mathrm{m}^{3}$ in Arugo motor park, $65.2 \mathrm{cfu} / \mathrm{m}^{3}$ in Okigwe motor park and $63.3 \mathrm{cfu} /$ $\mathrm{m}^{3}$ in Mbaise motor park. This high bacterial contamination of the motor parks could be attributed to high influx of people to the parks on daily basis and the beehive of activities that take place in the motor parks involving people who are traveling and those arriving at the park. Hence, this contributes to the high microbial load of the toilets as people go into the toilets to ease themselves. Ultimately, the behavior of toilet users also affects the level of indoor air quality within the toilet, which include not flushing the toilet properly, littering the toilet floor, among others.

The frequency of Bacteria and Fungi in the toilets across the parks are as follows; Imo Transport Company motor park $32.1 \%$ and $35.0 \%$, Arugo motor park $19.6 \%$ and $24.3 \%$, Okigwe motor park $23.2 \%$ and $21.4 \%$ and Mbaise motor park $25.0 \%$ and $19.4 \%$ respectively. It has been documented that human population and activities affect the concentration of Bacteria which are released through brisk movement, talking, coughing and sneezing. ${ }^{10,11}$ The presence of high number of visitors, wetness of toilet floors, lack of litter bins and refuse lids and lack of ownership of some public toilets must have resulted in the increase in airborne microbial load.

Staphylococcus aureus was observed to be the most isolated bacteria which could be attributed to the ubiquitous nature of the organism. This is similar to the result obtained by Ekhaise et al. ${ }^{9}$ in Benin in a study on indoor assessment of air. Staphylococcus aureus has been associated with Community Acquired Methicillin Resistant Staphylococcus aureus, urinary tract infections, skin infections and food poisoning. ${ }^{12}$ Bacillus cereus isolated from the toilets has also been linked to food poisoning which could cause a serious problem when proper hygienic standards are not maintained by toilet users.

\section{Conclusion}

The result of microbial assessment of indoor air of public toilets in selected motor parks across Owerri, revealed that the indoor air of the toilets, especially, the Imo Transport Company (ITC) motor park is not hygienic when compared to the WHO standard values of indoor air, which had a maximum limit for air borne bacteria count placed at $100 \mathrm{cfu} / \mathrm{m}^{3}$ and fungi $50 \mathrm{cfu} / \mathrm{m}^{3}$. Hence, the indoor air may pose a health risk to travelers and visitors who may visit the toilets before embarking on their journey. Staphylococcus aureus and Bacillus cereus which are implicated in food poisoning and Aspergillus $s p$ were among the indoor air contaminants of the toilets, these poses a serious health threat to toilet users. Contacts with these indoor microbes by individuals directly or indirectly place the individuals at risk of contracting an infection. Therefore, the findings of this study suggest the establishment of a sanitary task force as a measure to maintain sanitary standards in these toilets, thereby, forestalling undesirable consequences.

\section{Acknowledgments}

None.

\section{Conflicts of interest}

The authors declare no conflicts of interest.

\section{Funding}

None.

\section{References}

1. Muhamad darus F, Zain ahmed A, Talib M. Preliminary Assessment of Indoor air Quality in Terrace House. Health and Environmental Journal. 2011;2(2):8-14.

2. Stryjakowska-sekwska M, Piotraszewska-pajak A, Nowicki M. Microbiological Quality of Indoor air in University rooms. Polish Journal of Environmental Study. 2007;16(14):623-632.

3. Mirbahar AM, Memon BA. Bacteriological Monitoring through air sampling in Different Locations of Teaching Hospital (Civil Hospital Sukkur). Journal of Applied Environmental Sciences. 2005;1(1):13-15.

4. http://www.asumag.com/mag/

5. Jain SK, Persuad D, Perl TM, et al. Nosocomial Malaria and Saline Flush. Emerg Infect Dis. 2005;11(7):1097-1099. 
6. Nakajima K, Kasegawa M, Suzuki M, et al. Evaluation of Odour from Portable Toilets in a four-bed Hospital ward. Gerontechnology. 2003;2(4):324-331.

7. Jung JS, Hui KN, Man LK, et al. Toilet Cleanliness in Raffles Girls School. Raffles Girls School, Singapore. 2003.

8. Augustowska M, Dutkiewicz J. Variability of Airborne Micro-flora in a Hospital ward within a period of one year. Annals of Agricultural and Environmental Medicine. 2006;13(1):99-106.

9. Ekhaise FO, Isitor EE, Idehen O, et al. Airborne Microflora in the Atmosphere of a Hospital Environment of University of Benin Teaching
Hospital (UBTH) Benin City, Nigeria. World Journal of Agricultural Science. 2010;6(2):66-170.

10. Gerardt P, Murray EG, Wood AW, et al. Methods for General and Molecular Bacteriology. Asia Press, Washingto, US, 1994. pp. 791.

11. Berneth HL, Hunter BB. Illustrated Genera Imperfect Fungi. 3rd edn, Burgress, New York, USA, 1972. pp. 230-241.

12. Murray PR, Baron EJ, Pfaller MA, et al. Manual of Clinical Microbiology. 6th edn, American Society of Microbiology Press, Washington, US, 1995. pp. 282-293. 